\title{
Platelet function defects in chronic alcoholism
}

\author{
D P MIKHAILIDIS, W J JENKINS, M A BARRADAS, J Y JEREMY, P DANDONA
}

\begin{abstract}
Platelet function in alcoholic patients was assessed on admission and during abstinence in hospital. On admission platelets from these patients were significantly less responsive (percentage aggregation and thromboxane $A_{2}$ release) to conventional in vitro aggregating agents (adrenaline, adenosine diphosphate, and collagen) than platelets from healthy, moderate drinkers. Initially, platelet counts in platelet rich plasma tended to be low and the Simplate II bleeding times frequently prolonged. Platelet aggregation and thromboxane $A_{2}$ release, however, were inhibited even in patients with normal platelet counts on admission. Platelet aggregation and thromboxane $A_{2}$ release returned to normal or became hyper-responsive during two to three weeks of abstinence. Platelet counts rose during this period, the largest responses occurring in those patients with the lowest counts on admission. Bleeding times reverted to normal during abstinence and correlated significantly with changes in platelet aggregation, thromboxane $A_{2}$ release, and platelet count and with the estimated ethanol consumption during the week before admission.

Chronic, heavy alcohol ingestion evidently exerts an inhibitory effect on platelet function even in the absence of alcohol in the blood, and this phenomenon is reversible on abstaining. The impaired platelet function, together with the reduced platelet count, may contribute to the bleeding diathesis associated with chronic alcoholism and to the increased incidence and recurrence of gastrointestinal haemorrhage associated with excessive alcohol intake.
\end{abstract}

\footnotetext{
Metabolic Unit, Department of Chemical Pathology and Human Metabolism, Royal Free Hospital and School of Medicine, London NW3 2QG

D P MIKHAILIDIS, MB, MSC, lecturer and honorary senior registrar $M$ A BARRADAS, BSC, research assistant

J Y JEREMY, MSC, research fellow

P DANDONA, DPHIL, MRCP, senior lecturer and director, metabolic unit

Medical Unit, Royal Free Hospital and School of Medicine, London

W J JENKINS, MD, MRCP, lecturer and honorary senior registrar

Correspondence to: Dr Dandona.
}

\begin{abstract}
Introduction
We previously reported that the release of thromboxane $A_{2}$ (a vasoconstrictor and stimulator of platelet aggregation) from platelets of normal subjects is significantly reduced by relatively low concentrations of ethanol $(11-15 \mathrm{mmol} / \mathrm{l} ; 50-70 \mathrm{mg} / 100 \mathrm{ml})$ in vivo and in vitro, though at these concentrations platelet aggregation was not significantly affected. ${ }^{1}$ These observations led us to suggest that the inhibition of thromboxane $A_{2}$ release may be responsible, at least in part, for the reported association between moderate ethanol intake and a decreased incidence of vascular disease. Furthermore, impaired platelet function may be partly responsible for the bleeding diathesis associated with chronic alcoholism. ${ }^{1.7}$ In experiments performed with platelets obtained from healthy volunteers, however, the inhibitory effect of ethanol on platelet thromboxane $\mathrm{A}_{2}$ release was transient, and high concentrations of ethanol $(>43$ $\mathrm{mmol} / \mathrm{l} ;>200 \mathrm{mg} / 100 \mathrm{ml}$ ) were required to inhibit platelet aggregation in vitro. We have now studied alcoholic patients to see whether chronic exposure to ethanol results in more pronounced or sustained changes in platelet function.
\end{abstract}

\section{Patients and methods}

Twenty seven alcoholic patients ( 15 men, 12 women; median age 42 years, range 28-64) were studied within 24 hours of admission to the Royal Free Hospital. The patients were admitted for assessment of liver disease and for detoxification. None of the patients had gastrointestinal haemorrhages, anaemia, decompensated cirrhosis, vascular disease, or neurological sequelae of alcohol abuse. All patients were regularly ingesting daily more ethanol than the upper limit of safe drinking ( $80 \mathrm{~g}$ for men, $40 \mathrm{~g}$ for women). ${ }^{8}$ Twelve of these patients (eight men, four women) were also studied during abstinence as inpatients for up to three weeks. Liver biopsy showed that the principal abnormality was fatty liver in 15 patients, cirrhosis in nine, and alcoholic hepatitis in two. In one patient the histological appearance was normal. Histological findings in the 12 patients followed up during abstention were fatty liver in six, fatty liver plus mild alcoholic hepatitis in one, alcoholic hepatitis in one, cirrhosis (plus alcoholic hepatitis) in two, and cirrhosis in two.

Patients who had taken medication during the two weeks before admission were excluded. During the period of admission several patients received either chlormethiazole or chlordiazepoxide to control alcohol withdrawal symptoms. Informed consent was obtained from all patients.

Controls were 10 healthy volunteers (six men, four women; median age 30 
years, range 24-37) who had not taken any drugs in the previous two weeks and who drank less than $40 \mathrm{~g}$ ethanol daily. Controls were sampled at least 24 hours after the ingestion of any alcohol.

\section{MEASUREMENTS IN PATIENTS AND CONTROLS}

Platelet aggregation-Venous blood was collected in sodium citrate and samples of platelet rich and platelet poor plasma prepared by centrifugation..$^{9}$ Platelet rich plasma was kept at $37^{\circ} \mathrm{C}$ thereafter, since cooling influences platelet function. ${ }^{10}$ Platelet aggregation tests were performed in a dual channel Chronolog aggregometer. ${ }^{19}$ Results are expressed as the percentage fall in optical density three minutes after the addition of

TABLE I-Correlation between bleeding time and other variables assessed in alcoholic patients

\begin{tabular}{|c|c|c|}
\hline Correlation of bleeding time with: & $\begin{array}{l}\text { Spearman's } \\
\text { correlation } \\
\text { coefficient } \\
\left(\mathbf{r}_{\mathrm{s}}\right)\end{array}$ & $\mathrm{p}$ \\
\hline $\begin{array}{l}\text { Percentage platelet aggregation }(\mathrm{n}=27) \text { after: } \\
\text { Adenosine diphosphate }(10 \mu \mathrm{mol} / 1 ; 27 \mu \mathrm{g} / 100 \mathrm{ml}) \\
\text { Adrenaline }(5 \mu \mathrm{mol} / 1 ; 91.6 \mu \mathrm{g} / 100 \mathrm{ml}) \\
\text { Collagen }(1 \mathrm{mg} / \mathrm{l})\end{array}$ & $\begin{array}{l}-0.64 \\
-0.54 \\
-0.54\end{array}$ & $\begin{array}{l}<0.001 \\
<0.005 \\
<0.005\end{array}$ \\
\hline $\begin{array}{l}\text { Platelet thromboxane } \mathrm{A}_{2} \text { release (ng thromboxane } \mathrm{B}_{2} / 10^{8} \text { platelets; } \\
\mathrm{n}=18) \text { after: } \\
\text { Adenosine diphosphate }(10 \mu \mathrm{mol} / 1 ; 427 \mu \mathrm{g} / 100 \mathrm{ml}) \\
\text { Adrenaline }(5 \mu \mathrm{mol} / 1 ; 91 \cdot 6 \mu \mathrm{g} / 100 \mathrm{ml}) \\
\text { Collagen }(1 \mathrm{mg} / \mathrm{l}) \\
\text { Platelet count in platelet rich plasma }\end{array}$ & $\begin{array}{l}-0.56 \\
-0.48 \\
-0.49 \\
-0.47\end{array}$ & $\begin{array}{r}0.02 \\
0.05 \\
<0.05 \\
<0.02\end{array}$ \\
\hline $\begin{array}{l}\text { Estimated ethanol intake ( } g / \text { day) during week before admission } \\
(n=17)\end{array}$ & -0.75 & $<0.001$ \\
\hline
\end{tabular}

TABLE III-Median (range) platelet thromboxane $B_{2}$ release (ng thromboxane $\mathrm{B}_{2} / 10^{8}$ platelets) in healthy controls and alcoholic patients on admission (day 1) and after abstention (days 8 and 15)

\begin{tabular}{|c|c|c|c|}
\hline \multirow[b]{2}{*}{ Sample time } & \multicolumn{3}{|c|}{ Aggregating agent } \\
\hline & $\begin{array}{c}\text { Adrenaline } \\
(5 \mu \mathrm{mol} / 1 ; \\
91.6 \mu \mathrm{g} / 100 \mathrm{ml})\end{array}$ & $\begin{array}{c}\text { Adrenosine } \\
\text { diphosphate } \\
(10 \mu \mathrm{mol} / 1 ; \\
427 \mu \mathrm{g} / 100 \mathrm{ml})\end{array}$ & $\begin{array}{l}\text { Collagen } \\
(1 \mathrm{mg} / \mathrm{l})\end{array}$ \\
\hline $\begin{array}{l}\text { Day } 1(n=8) \\
\text { Day } 8(n=8) \\
\text { Day } 15(n=8)\end{array}$ & $\begin{array}{c}0.5+H(0-4) \\
2+H(0-8) \\
9 \star \star(0-33)\end{array}$ & $\begin{array}{c}1+(0-3) \\
1+(0-8) \\
6^{\star \star}(1-7)\end{array}$ & $\begin{array}{c}5+(0 \cdot 5-14) \\
6+(1-16) \\
10^{\star}(6-15)\end{array}$ \\
\hline Controls $(n=10)$ & $11(6-22)$ & $3(0 \cdot 5-5)$ & $18(10-28)$ \\
\hline
\end{tabular}

Patients on day $1 v$ same patients on day 8 or $15:{ }^{\star} \mathrm{p}=0.05 ;{ }^{\star \star} \mathrm{p}<0.01$ (Wilcoxon test). Patients $v$ controls: $\nmid \mathrm{p}<0.01 ; \mathrm{t} \mathrm{p}<0.005 ; \mathrm{t}+\mathrm{p}<0.002$ (Mann-Whitney test).

tion coefficient $\left(r_{\mathrm{s}}\right)$. All results were analysed using two tailed nonparametric statistics (Mann-Whitney tests for unpaired results, Wilcoxon test for paired results).

\section{Results}

Platelet count-In the 12 patients followed up during abstinence the platelet count in platelet rich plasma rose from a median of 220 (range 55$540) \times 10^{9} / 1$ on day 1 to $310(100-528) \times 10^{9} / 1$ on day 8 and then to $380(211-$ $858) \times 10^{9} / 1$ on day 15 . This rise was statistically significant (day $1 v$ day 8 and day $1 v$ day $15 \mathrm{p}<0.01$ ). A similar pattern was observed with platelet counts in whole blood, which correlated significantly with the platelet counts in platelet rich plasma $\left(r_{s}=0.60 ; p<0.001\right)$. In five patients who were also

\begin{tabular}{|c|c|c|c|c|c|c|}
\hline \multirow[b]{3}{*}{ Sample time } & \multicolumn{6}{|c|}{ Aggregating agent } \\
\hline & \multicolumn{2}{|c|}{ Adrenaline } & \multicolumn{2}{|c|}{ Adenosine diphosphate } & \multicolumn{2}{|c|}{ Collagen } \\
\hline & $\begin{array}{c}0.5 \mu \mathrm{mol} / \\
(9 \cdot 2 \mu \mathrm{g} / \\
100 \mathrm{ml})\end{array}$ & $\begin{array}{c}5 \mu \mathrm{mol} / / \\
(91 \cdot 6 \mu \mathrm{g} / \\
100 \mathrm{ml})\end{array}$ & $\begin{array}{c}2 \mu \mathrm{mol} / 1 \\
(85 \cdot 4 \mu \mathrm{g} \\
100 \mathrm{ml})\end{array}$ & $\begin{array}{c}10 \mu \mathrm{mol} / / \\
(427 \mu \mathrm{g} / \\
100 \mathrm{ml})\end{array}$ & $0.5 \mathrm{mg} / \mathrm{l}$ & $1 \mathrm{mg} / \mathrm{l}$ \\
\hline Day 1 & $\begin{array}{c}0 \\
(0-13) \\
n=11\end{array}$ & $\begin{array}{l}14+t \\
(5-75) \\
n=15\end{array}$ & $\begin{array}{l}17+t \\
(0-62) \\
n=15\end{array}$ & $\begin{array}{c}56 \\
(6-88) \\
n=15\end{array}$ & $\begin{array}{c}0+t \\
(0-61) \\
\mathbf{n}=15\end{array}$ & $\begin{array}{l}41 \mathrm{Ht} \\
(0-84) \\
\mathrm{n}=15\end{array}$ \\
\hline Day 8 & $\begin{array}{c}0 \\
(0-55) \\
\mathbf{n}=11\end{array}$ & $\begin{array}{l}29+t \\
(0-70) \\
n=15\end{array}$ & $\begin{array}{c}13 t \\
(0-79) \\
n=12\end{array}$ & $\begin{array}{c}63 \\
(22-82) \\
n=12\end{array}$ & $\begin{array}{l}0+t \\
(0-71) \\
n=15\end{array}$ & $\begin{array}{l}50+t+ \\
(0-70) \\
n=15\end{array}$ \\
\hline Day 15 & $\begin{array}{l}13^{\star} \\
(0-78) \\
n=11\end{array}$ & $\begin{array}{l}66^{\star} \\
(9-82) \\
n=12\end{array}$ & $\begin{array}{c}49^{\star} \\
(0-90) \\
\mathrm{n}=12\end{array}$ & $\begin{array}{c}79^{\star} \\
(15-92) \\
\mathrm{n}=12\end{array}$ & $\begin{array}{c}58^{\star \star} \\
(0-90) \\
\mathrm{n}=12\end{array}$ & $\begin{array}{l}64^{\star \star} \\
(0-90) \\
\mathrm{n}=12\end{array}$ \\
\hline Controls $(n=10)$ & $\begin{array}{c}0 \\
(0-10)\end{array}$ & $\begin{array}{c}70 \\
(66-78)\end{array}$ & $\begin{array}{c}46 \\
(24-71)\end{array}$ & $\begin{array}{c}75 \\
(68-82)\end{array}$ & $\begin{array}{c}44 \\
(20-61)\end{array}$ & $\begin{array}{c}79 \\
(72-89)\end{array}$ \\
\hline
\end{tabular}

Patients on day $1 v$ same patients on day 8 or day $15:{ }^{\star} \mathrm{p}=0.05 ;{ }^{\star \star} \mathrm{p}<0.01$ (Wilcoxon test).

Patients $v$ controls: $\mathrm{tp}<0.05 ; \mathrm{tp}<0.02 ; \mathrm{ttp}<0.002$ (Mann Whitney test).

agonists. ${ }^{1910}$ Tables II and III show the sampling times, numbers of patients and controls, and the final concentrations of agonists used.

Platelet thromboxane $A_{2}$ release, packed cell volume, and platelet countRelease of platelet thromboxane $A_{2}$ (measured as thromboxane $B_{2}$, the stable, spontaneous breakdown product of thromboxane $A_{2}$ ) and platelet counts in platelet rich plasma were measured as described. ${ }^{1}$ Platelet counts in whole blood and the packed cell volume were determined using a Coulter counter, model S. Table III shows the sampling times, number of patients and controls, and agonist concentrations.

Bleeding time was measured using the Simplate II procedure (General Diagnostics, Mount Plains, New Jersey). Bleeding time was measured in alcoholics $(n=27)$ within 24 hours of admission; on days 8 and 15 in five patients who had prolonged bleeding times on admission (see fig 1); and in nine control subjects.

Blood ethanol concentrations were assayed as described.

Statistical analyses and presentation of results-Results are presented as median and range. Correlations were performed using Spearman's correla- sampled on day 22 the platelet count in platelet rich plasma was 280 (222$360) \times 10^{9} / 1$. Large increases in platelet count were seen only in the group of patients with the lowest platelet counts initially, but the changes in platelet counts were similar whatever the histological picture in the liver. Bleeding time correlated significantly with platelet counts in platelet rich plasma (table I). Some patients with normal counts in platelet rich plasma had prolonged bleeding times.

Platelet aggregation in the alcoholic patients was initially significantly less than that in controls but increased progressively to reach normal by day 15 (table II). In some alcoholic patients platelet aggregation in vitro was hyperresponsive to agonists after two to three weeks of abstinence. On admission platelet aggregation was inhibited even in patients with normal platelet counts. Packed cell volume did not change appreciably during the study period. Platelet aggregation patterns were similar whatever the histological findings in the liver. There was a significant inverse correlation between bleeding time and platelet aggregation (table I).

Platelet thromboxane $A_{2}$ release-The changes in thromboxane $\mathrm{A}_{2}$ release 
paralleled those of platelet aggregation (table III). On admission release was low even in patients with normal platelet counts. There was a significant inverse correlation between bleeding time and platelet thromboxane $\mathbf{B}_{2}$ release (table I).

Bleeding time was significantly $(\mathrm{p}<0.002 ;$ Mann-Whitney test) prolonged in the alcoholic patients on admission $(n=27$; median $7 \mathrm{~min} 20 \mathrm{~s}$; range $4 \mathrm{~min} 30 \mathrm{~s}$ to $>25 \mathrm{~min}$ ) compared with control subjects $(n=9$; median $4 \mathrm{~min} 40 \mathrm{~s}$; range $4 \mathrm{~min} 10 \mathrm{~s}$ to $6 \mathrm{~min} 5 \mathrm{~s}$ ). Figure 1 shows the sequential return of bleeding time to normal in five patients during two weeks of abstinence and figure 2 the bleeding times in relation to ethanol intake in a selection of patients with histological evidence of cirrhosis or fatty liver. Table I shows the correlation $\left(r_{s}\right)$ between the bleeding time and other variables.

Blood ethanol concentrations-Ethanol was not detected in any of the samples.

\section{Discussion}

Our results show that platelet aggregation and thromboxane $A_{2}$ release are impaired in chronic alcoholism. These changes, together with the thrombocytopenia which was present in some patients, contributed to the prolonged bleeding time. These abnormalities tended to correct after two weeks of abstinence. In some cases this correction was exaggerated, resulting in thrombocytosis and enhanced platelet aggregation and release of thromboxane $A_{2}$. To our knowledge this is the first study to show a significant correlation

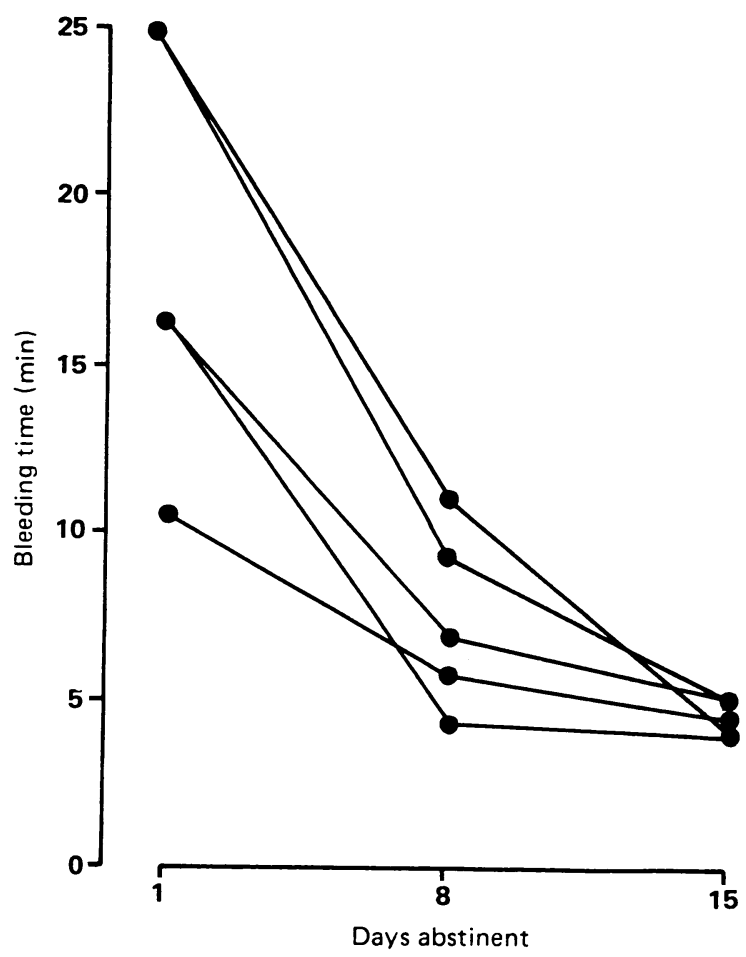

FIG 1-Effect of abstinence on bleeding time in five alcoholic patients.

between bleeding time and platelet thromboxane $A_{2}$ release in any pathological state.

Our findings agree with those of others who showed that whole blood platelet counts rise with abstinence. ${ }^{46}$ One earlier study, however, sampled only thrombocytopenic alcoholics and therefore failed to show that rebound thrombocytosis is minimal if initial counts are normal. ${ }^{4}$ In another study the whole blood platelet count rose after abstention, but all counts remained essentially within the normal range. ${ }^{5}$ The absence of thrombocytopenia in this latter study may have been due to the absence of patients with severe alcoholism. ${ }^{6}$ In a third study there was no correlation between liver function values and the thrombocytosis response. ${ }^{6}$ This finding is compatible with the lack of correlation between histological abnormality in the liver and rebound thrombocythaemia in the present study. The initial inhibition of platelet aggregation and its subsequent recovery or hyperactivity have also been documented, 5 though concomitant changes in bleeding time and thromboxane $\mathrm{A}_{2}$ release have not; nor were histological findings documented in these earlier studies. ${ }^{46}$

The changes we describe may be relevant to the bleeding tendency in chronic alcoholism, ${ }^{3}$ since some studies, ${ }^{711}$ but not others, ${ }^{11}$ have shown that the recurrence of gastrointestinal bleeding is increased in patients who do not abstain.

The mechanisms responsible for the inhibition of platelet function in chronic alcoholism remain unclear. Nevertheless, based on our findings it appears that thrombocytopenia plays a part, since aggregation was diminished in experiments where platelet rich plasma was diluted with autologous platelet poor plasma. ${ }^{12}$ Thrombocytopenia may also impair thromboxane $\mathrm{A}_{2}$ release, since we have

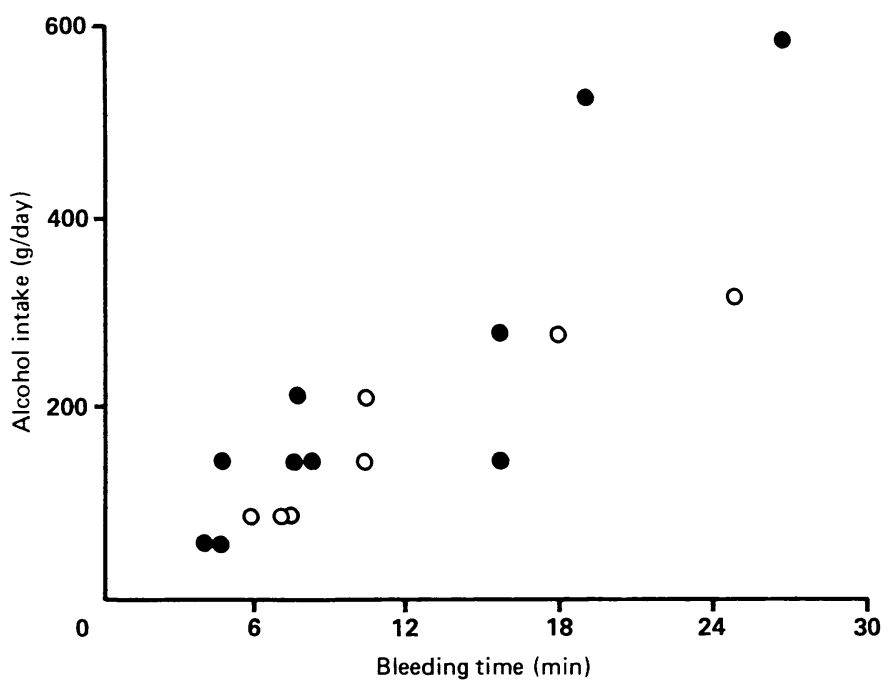

FIG 2-Relation between bleeding time and estimated ethanol intake in alcoholic patients with cirrhosis $(O)$ and fatty $\operatorname{liver}(\mathbf{O})$.

found that when platelet rich plasma from healthy subjects is diluted with autologous platelet poor plasma the amount of thromboxane $A_{2}$ release, expressed per $10^{8}$ platelets, noticeably decreases when the platelet count in platelet rich plasma falls below $100-150 \times 10^{9} / 1$ (unpublished observations). The impaired platelet aggregation and release of thromboxane $A_{2}$ in chronic alcoholics, however, is influenced by factors other than the platelet count, since inhibition was seen even when counts were well within the normal range. Interestingly in this context, blood ethanol concentrations achieved in vivo alter the properties of cell membranes, and chronic excessive intake of ethanol results in more protracted changes in membrane properties. ${ }^{13}$ These changes are compatible with the transient impairment of platelet function seen after the ingestion of ethanol in moderate drinkers ${ }^{1}$ and the more persistent inhibition we found in alcoholics in the absence of alcoholaemia. Future studies should therefore establish whether thromboxane $A_{2}$ synthesis is inhibited because of impairment of membrane related enzymes (phospholipase $\mathrm{A}_{2}$ ) or of intracellular enzymes (cyclo-oxygenase, thromboxane $A_{2}$ synthase).

The observed rebound thrombocythaemia suggests that after abstention the bone marrow is no longer suppressed by ethanol and it releases young platelets which are probably hyperactive. This view is compatible with the evidence that platelet size changes after abstention ${ }^{14}$ and that megakaryocyte maturation is influenced by ethanol. ${ }^{15}$

In conclusion, our study supports the view that platelet function in chronic alcoholics is impaired even in the absence of thrombocytopenia or alcoholaemia. These defects were reversible 
on abstention. This latter observation, together with the significant correlation between the prolongation of the bleeding time and the intake of ethanol, suggests that abstention may be beneficial in preventing recurrences of gastrointestinal bleeding. Whether the inhibition we found was an exaggeration of changes occurring in moderate drinkers remains to be seen. Such a concept, however, might account for the observed reduction in the incidence of cardiovascular disease in moderate drinkers. ${ }^{1}$

The preliminary findings of this study were presented at a meeting of the and Professor $\mathrm{N}$ McIntyre for permission to study their patients and Mrs P Dale for secretarial help.

\section{References}

1 Mikhailidis DP, Jeremy JY, Barradas MA, Green N, Dandona P. Effect of ethanol on vascular prostacyclin (prostaglandin $\mathrm{I}_{2}$ ) synthesis, platelet aggregation and platelet thromboxane release. BrMed J 1983;287:1495-8. British Society of Gastroenterology. ${ }^{16}$ We thank Professor Dame S Sherlock
2 Mikhalidis DP, Jenkins WY, Jeremy JY, Barradas MA, Dandona P. Ethanol and arterial disease. N Engl F Med 1984;311:537-8.

Cowan DH. Effect of alcoholism on hemostasis. Semin Hematol 1980;17:137-47.

4 Haselager EM, Vreeken J. Rebound thrombocytosis after alcohol abuse: a possible factor in the pathogenesis of thromboembolic disease. Lancet 1977;i:74-5.

5 Fink R, Hutton RA. Changes in the blood platelets of alcoholics during alcohol withdrawal. $f \mathrm{Clin}$ Pathol 1983;36:337-40.

6 Cowan DH, Hines JD. Thrombocytopenia of severe alcoholism. Ann Intern Med 1971;74:37-43. recurrent variceal hemorrhage in patients with cirrhosis. $N$ Engl f Med 1983;309:1539-42.

8 Rosalki SB. Alcoholism-an overview. In: Rosalki SB, ed. Comtemporary topics in clinical biochemistry. Vol 1. Clinical biochemistry of alcoholism. Edinburgh: Churchill Livingstone, 1985; 3-19.

9 Mikhailidis DP, Mikhailidis AM, Woollard ML, Dandona P. Protection of prostacyclin-like activity in human plasma - a non-enzymatic mechanism. Clin Sci 1982;62:177-81.

10 Mikhailidis DP, Hutton RA, Jeremy JY, Dandona P. Cooling decreases the efficiency of prostacyclin inhibitors of platelet aggregation. Microcirculation 1983;2:413-23.

11 Grace N. The misuse of cimetidine in patients with cirrhosis. Hepatology 1984;4:574.

12 Born GVR, Cross MJ. The aggregation of blood platelets. I Physiol 1963;168:178-95.

13 Lieber CS. Metabolism and metabolic effects of alcohol. Med Clin North Am 1984;68:3-31.

13 Lieber CS. Metabolism and metabolic effects of alcohol. Med Clin North Am 1984;68:3-31. 355-6. Haematol 1986;62:345-54

16 Jenkins WJ, Mikhailidis DP, Barradas MA, Jeremy JY, Dandona P. Impaired platelet function and prolonged bleeding time in chronic alcoholics. Gut 1984;25:A544.

(Accepted 28 July 1986) 7 Burroughs AK, Jenkins WJ, Sherlock S, et al. Controlled trial of propranolol for the prevention of

15 Levine RF, Spivak JL, Meagher RC, Sieber F. Effect of ethanol on thrombopoiesis. $\mathrm{Br} \mathcal{J}$

무

\section{YEARS AGO}

If the matter were not so serious, there would be something almost humorous in the pathetic appeal made by Dr. Farquharson, the other day, to the representative of the Office of Works, as to the unpleasant smells that have again been making themselves disagreeably permanent in the House of Commons. Mr. Fowler's own olfactory nerves had been affronted by the smells, and he had spoken about them to the Speaker, who could only suggest that universal panacea for all Parliamentary ills- the appointment of another Select Committee. Such a committee did, indeed, gravely discuss the question last year, and took the inevitable batch of evidence from experts and others. But nothing whatever was done, and now the same nuisance crops up again. It may suit the views of those who like to find a fanciful, rather than a common-sense, reason for everything, to allege that the smells arise from the burning of distant rubbish, or from the river. Less analytical noses ascribe the effluvia to a not very recondite origin-bad drains; and there is strong reason for believing that they are right. The whole of the drainage in that particular corner of Westminster, which includes the Houses of Parliament and the new Government offices, is thoroughly bad. There is a quite insufficient fall, the drainage-pipes are imperfect, and the leakage of sewage into the soil is an admitted fact. Members of the legislature cannot be accused of neglect of their own comfort; and we are surprised, therefore, that they take so meekly the nuisance of bad smells to which they are exposed. It surely does not need yet another Select Committee to prove that the effluvia exist, and need to be suppressed. The resources of the Office of Works ought to be equal to the discovery of the source of the mischief, and to its effectual stoppage for the future. Nor are honourable members likely to quarrel over the expense of freeing the Houses of Parliament from the unsolicited presence of sewer-gas. (British Medical fournal 1886;i:604.)

A correspondent with the hospital aid train belonging to the Society of the Knights of Malta, writes as follows:-

"It was not till dusk that the first batch of wounded arrived, and these had to be shifted from the arabas and ambulance waggons by the light of torches. The glare and flicker of this fitful light on the pain-stricken faces of the wounded had a most ghastly effect. As soon as the poor fellows neared the Ritter's train, they were taken in charge by the Knights of the Order, Prince Lichnowsky, his adjutant, Prince Lichtenstein, and the commanders of the train, Count d'Harnoucout, and Barons Mundy and Wallerskirchen. These gentlemen were untiring in their endeavours to make the transfer of their helpless passengers as painless as possible. The regular Ritter train has fifteen carriages, ten for the wounded and the rest for the officials, medical men, cooks, and stores. There are ten cots in each carriage for the sick, with invalid tables fitted over the beds. There is a stove in each car, and an attendant regulates the temperature and looks after the wants of the wounded. Directly the cars have their complement of passengers, cigars and cigarettes are handed round, and very few refuse the luxury of a smoke. Soup, meat, and bread, and wine are placed before each invalid; the attendants gently persuading and coaxing their charges, who are too sick to eat, to take a little soup or sup of wine. Drs. Baron Mundy, Heinrick, and Grunes are in attendance throughout the journey; there is an alarm bell in each ward, and they are on the spot immediately their services are required. I was in the commandant's car during the night when the alarm was sounded. Dr. Mundy was up in a moment, brandy-bottle under his arm, and instrument-case in hand. He was beside the sufferer seven cars off in less than a minute.

"No report is sent in by the Servian medical men, so the Ritter medical men have no knowledge of the cases in hand. The case in question was one of an appalling number of the same kind-blood-poisoning from neglect. The poor fellow's wounds had not been dressed for ten days after he fell at the Dragoman Pass. It was a simple flesh-wound in the leg. The slightest attention at first would have saved the man's life, and he now lay rotting and dying. He passed away during the night. I doubt if the poor fellow ever received more kindness during his life than now, when it was slowly ebbing from him, and from the hands of strangers. There are hundreds and hundreds of this kind of wounded who might be saved to the country, but for the stupid jealousy and mistrust of foreigners by Servian officials, who will not allow the numerous German and English surgeons, who have come to Servia with the best possible spirit, to render them service at the front." (British Medical fournal 1886;i:36.)

We have repeatedly called attention to the danger resulting from explosions of coal gas as affecting life and property, and it would appear that the lesson must be taught as long as illumination by gas exists. The last explosion, causing injury to three persons, occurred at Brixton, but only persons who are acccustomed to reading daily the provincial papers can form even an approximate idea of how frequently disasters occur owing to the carelessness with which the gas-supply is treated. Many accidents have resulted in public thoroughfares owing to the explosion of gas-mains, and the consequences have been lamentable. But until a separate record is kept and published of deaths from gas-explosions in houses, or the resulting casualties therefrom are brought together in tabular form, the full extent of the danger cannot be appreciated. The owner of a house, for instance, orders the meter to be turned off at a certain hour, and he fairly supposes that, when the domestics see that this is done, they will at once reverse the taps; it is to the neglect of this precaution that very many explosions are due. People are also apt to be careless about an escape of gas made evident, very faintly, by smell; it is not until the space between the joists and overhead ceilings are charged with the gas, and until an accidental flame is introduced, that they realise the danger. The destruction to life and property due to gas-explosions can only be obviated by constant precautions against faulty joints, cracked seams, and pinholes in the pipes; the only method of testing the soundness of pipes is by shutting off the gas at the meter, burning out the gas left in the pipes, and charging the pipes by a force pump with atmospheric air, the pump being placed in front of a mercury gauge. If, when the air has been forced into the pipes, and pumping has ceased, the gauge falls, it is certain that somewhere the air escapes, as would consequently the gas. An ingenious system of discovering the presence of leaks in gas-pipes was published by Mr. Eassie, C.E., of Argyll Street, London, some time ago, and is still practised by him with much success. (British Medical fournal 1886;ii:730.) 